\title{
Negative Schumm Test
}

National Cancer Institute

\section{Source}

National Cancer Institute. Negative Schumm Test. NCI Thesaurus. Code C35613.

A finding that indicates that a significant level of methemalbumin is not present in the blood. 